\title{
Urgensi Internalisasi Nilai-Nilai Ketahanan Nasional dalam Pembelajaran PPKn Tingkat SMP (Studi di Kabupaten Solok Selatan
}

Irwan, Junaidi Indrawadi, Atri Waldi

Program Studi Pendidikan Pancasila dan kewarganegaraan

Universitas Negeri Padang

irwanhamdi@fis.unp.ac.id

\begin{abstract}
ABSTRAK
Penelitian ini bertujuan untuk menganalisis implementasi konsep ketahanan nasional pada pembelajaran PPKn Tingkat SMP di Kabupaten Solok Selatan. Penelitian ini dilakukan dengan metode kualitatif dan teknik analisis deskriptif. Penelitian dilakukan terhadap guru-guru SMP yang tergabung dalam kelompok Musyawarah Guru Mata Pelajaran PPKn (MGMP) PPKn SMP dari seluruh kecamatan di Kabupaten Solok Selatan dengan jumlah 30 orang guru. Hasil penelitian ini menunjukkan bahwa perlu adanya internalisasi nilai-nilai ketahanan nasional di wilayah Solok Selatan. Penanaman nilai-nilai ketahanan nasional di wilayah Solok Selatan perlu di mulai sejak dini melalui kurikulum Pendidikan Kewarganegaraan di tingkat sekolah
\end{abstract}

\begin{abstract}
This study aims to analyze the implementation of the concept of national resilience in the learning of junior secondary level PPKn in South Solok Regency. This research was conducted with qualitative methods and descriptive analysis techniques. The study was conducted on junior high school teachers who are members of the PPKn Middle School Teachers' Consultation Group (MGMP) group from all sub-districts in South Solok Regency with a total of 30 teachers. The results of this study indicate that there is a need to internalize the values of national resilience in the South Solok region. Planting national resilience values in the Solok Selatan area needs to be started early through the Citizenship Education curriculum at the school level
\end{abstract}

\section{PENDAHULUAN}

Desentralisasi pada dasarnya merupakan konsep tata kelola pemerintahan dimana adanya penyerahan sebagian wewenang dari pemerintah pusat ke pemerintah di daerah. Menurut Pratikno (2003), kegagalan pemerintahan Sukarno dan Soeharto dalam membangun

dukungan daerah terhadap pemerintah nasional merupakan rujukan obyektif bagi perlunya desentralisasi. Desentralisasi yang pada ruhnya diharapkan sebagai wujud apresiasi terhadap keberagaman di Indonesia telah melahirkan konsep otonomi daerah. Pelaksanaan otonomi 
daerah didasarkan pada UU No. 22 tahun 1999 yang kemudian diganti dengan UU No. 22 tahun 2004. Konsep otonomi daerah berarti membangun kemandirian daerah dalam mengelola pemerintahan setempat termasuk dalam aspek pengambilan keputusan politik maupun administratif tanpa adanya intervensi dari pemerintah pusat. Konsep otonomi daerah berkaitan erat dengan konsep pemekaran wilayah karena pada dasarnya pemekaran wilayah lahir dari semangat kemandirian daerah dan dimaksudkan untuk menciptakan pemerintahan yang efektif dan efisien dalam rangka menyejahterakan masyarakat. Meskipun dalam realita saat ini beberapa daerah hasil pemekaran justru mendapatkan persoalan serius misalnya infrastruktur yang minim, kurangnya dukungan daerah induk, sengketa batas wilayah, hingga persoalan pembangunan sumber daya manusia. Nurul Aini (2012) didalam jurnal Sosiologi menyatakan bahwa kebijakan pemekaran wilayah perlu ditilik kembali karena alih-alih menyejahterakan, outputnya justru meningkatkan eskalasi konflik antar daerah. Jika konflik antar daerah pemekaran dengan daerah induk masih terjadi maka hal itu akan mempengaruhi tata kelola pemerintahan yang justru merugikan masyarakat. Meskipun demikian, penelitian yang dilakukan oleh Susanti (2014) di Kabupaten Lampung utara menunjukkan bahwa kualitas infrastruktur dan kesejahteraan ekonomi makin meningkat pasca pemekaran.

Disini dapat dipahami bahwa pemekaran suatu daerah harus didukung oleh segenap potensi daerah tersebut baik terutama di segi kualitas sumberdaya manusia dan sumberdaya alamnya. Aspek Sumber Daya Manusia (SDM) menjadi faktor utama dalam pembangunan masyarakat karena manusia merupakan roda penggerak pembangunan sehingga membutuhkan perhatian serius untuk dituntaskan. Kualitas SDM suatu daerah akan menentukan kualitas daerah secara menyeluruh. Sementara pembangunan infrastruktur mencerminkan tingkat kemajuan daerah secara finansial. Kualitas SDM dan Infrastruktur akan mempengaruhi ketahanan suatu daerah yang pada gilirannya mempengaruhi ketahanan nasional. Menurut Djadijono (2006), terdapat empat aspek prioritas yang menjadi indikator kelemahan maupun kekuatan daerah yaitu tingkat pendidikan, fasilitas kesehatan, infrastruktur, dan pemberdayaan ekonomi masyarakat. Jika pemerintah daerah mampu dalam memenuhi empat indikator mendasar ini maka dapat dikatakan bahwa daerah tersebut telah cukup kuat dan mampu bersaing dengan daerah lainnya. Kekuatan daerah akan menunjang ketahanan daerah yang secara akumulatif menjadi daya dukung dalam 
mewujudkan ketahanan nasional. Ketahanan sebuah bangsa sangatlah penting bagi kelangsungan kehidupan manusia di wilayah tersebut karena berkaitan dengan kemampuan bangsa untuk mempertahankan kesatuan dan persatuannya serta memperkuat elemen pendukungnya (goegrafis, ekonomi, politik, sosial budaya, kemampuan militer, dan kemauan masyarakat). Dengan kata lain yakni kemampuan untuk menghadapi semua ancaman yang dihadapinya sehingga memiliki kemampuan melangsungkan kehidupannya dalam tujuan mencapai kesejahteraan bangsa.

\section{METODE PENELITIAN}

Penelitian ini dilakukan dengan metode kualitatif dan teknik analisis deskriptif. Penelitian dilakukan terhadap guru-guru SMP yang tergabung dalam kelompok Musyawarah Guru Mata Pelajaran PPKn (MGMP) PPKn SMP dari seluruh kecamatan di Kabupaten Solok Selatan dengan jumlah 30 orang guru. Data dikumpulkan melalui teknik observasi langsung, wawancara mendalam serta dokumentasi dan data pendukung lainnya. Observasi dilakukan terhadap proses belajar mengajar dan analisis kurikulum PPKn di SMP. Observasi juga dilakukan terhadap para guru PPKn untuk mengetahui kompetensi dan pengetahuan mereka terhadap konsepsi ketahanan nasional. Teknik pengumpulan data dengan wawancara dilakukan terhadap beberapa pihak yang berperan dalam penelitian ini yaitu Ketua MGMP PPKn SMP Solok Selatan dan perwakilan guru-guru. Selain melalui observasi dan wawancara, peneliti juga melengkapi hasil penelitian dengan data yang didapatkan melalui teknik foto, video dan sumber-sumber daring.

\section{HASIL DAN PEMBAHASAN}

1. Konsepsi Ketahanan Nasional dalam Konteks Kewilayahan

Konsepsi

ketahanan

bangsa untuk konteks Indonesia dikenal dengan nama Ketahanan Nasional yang dicetuskan oleh Lembaga Pertahanan Nasional (Lemhanas) pada tahun 1970-an. Ketahanan Nasional dapat dimaknai sebagai sebuah kondisi dinamis bangsa Indonesia yang merupakan integrasi dan kondisi tiap-tiap aspek dari kehidupan bangsa dan negara. Konsepsi Ketahanan Nasional menurut Marsma TNI (Purn) H.A. Gani Jusuf, SIP (2011: 1) yaitu seluruh aspek kehidupan maksimal manusia yang dirinci dalam 8 (delapan) gatra, terdiri dari 3 (tiga) gatra alamiah yaitu geografis, demografi, dan sumber kekayaan alam sebagai "modal dasar" pembangunan serta 5 (lima) gatra non-alamiah yaitu ideologi, politik, sosial-budaya, ekonomi serta gatra pertahanan dan keamanan (hankam) yang harus dibina dan dibangun secara 
nasional, agar tercipta suatu kondisi yang memungkinkan pembangunan nasional berjalan lancar dan berhasil. Tiga gatra alami berarti adanya tiga aspek yang secara alamiah menjadi aspek yang mempengaruhi upaya untuk mewujudkan ketahanan nasional yang tangguh yaitu dari aspek kependudukan, sumber daya manusia dan faktor geografis atau kewilayahan. Seperti dua sisi mata uang, ketiga aspek ini dapat memberikan aspek positif jika dapat dimanfaatkan dengan tepat dan optimal serta dapat juga berdampak negatif bagi negara dan masyarakat jika gagal dan tidak mampu memanfaatkannya dengan baik dan benar.

Lima gatra non-alamiah atau gatra buatan berarti adanya lima aspek yang harus diupayakan terlaksana dengan baik. Pertama, aspek ideologi menjadi faktor penting dalam mewujudkan pembangunan dan menjaga stabilitas ketahanan nasional. Pancasila sebagai ideologi negara sudah menjadi "way of life" bagi masyarakat Indonesia sejak kemerdekaan hingga sekarang. Kedua, aspek politik sebagai dimensi esensial dalam menjalankan pemerintahan dan mewujudkan tata kelola pemerintahan yang baik (good governance). Konstelasi politik dan pemerintahan yang stabil akan berpengaruh besar bagi ketahanan negara. Ketiga, aspek ekonomi juga merupakan dimensi yang terpenting dalam rangka melaksanakan pembangunan.
Indikator keberhasilan ekonomi dapat dilihat dari meningkatnya kesejahteraan masyarakat, daya serap tenaga kerja serta penurunan angka kemiskinan. Aspek yang keempat yaitu aspek sosial-budaya menjadi hal yang esensial untuk menciptakan keteraturan dalam masyarakat yang diwarnai dengan keberagaman budaya dan adat istiadat. Sementara aspek kelima menyangkut persoalan pertahanan dan keamanan nasional Indonesia yang merupakan tanggung jawab bersama antara pemerintah, masyarakat dengan unsur pertahanan dan keamanan Indonesia yakni TNI-Polri. Sinergi yang kuat antara ketiga elemen tersebut dapat memperkuat ketahanan nasional Indonesia sekaligus mempertegas eksistensi Indonesia sebagai negara yang berdaulat.

Ketahanan Nasional dalam konteks kewilayahan artinya membangun ketahanan nasional yang kuat dan tangguh harus dimulai dari subordinate system yaitu pemerintahan di daerah. Secara administratif, wilayah Indonesia didefinisikan dalam bentuk Propinsi, Kabupaten/Kota, serta wilayah administratif di bawahnya. Berdasarkan hal itu maka dalam membangun ketahanan wilayah juga dapat dimulai dari kabupaten atau kota sekaligus sebagai amanat desentralisasi. Semakin kecil cakupan wilayahnya maka tentu saja upaya untuk mewujudkan 
ketahanan nasional yang kuat dan tangguh akan lebih mudah dicapai. Dalam konteks yang lebih khusus, ketahanan wilayah harus dimulai dari setiap individu sebagai warga negara. Konsep ini dikenal dengan ketahanan pribadi. Gambar berikut menjelaskan proses akumulasi dari ketahanan pribadi yang menjadi kekuatan bagi suatu daerah atau wilayah. Kemudian ketahanan di setiap wilayah menjadi tolak ukur ketahanan nasional.
2. Ketahanan Wilayah Solok Selatan

Salah satu daerah hasil pemekaran wilayah di Indonesia adalah Kabupaten Solok Selatan yang merupakan salah satu dari 19 kota dan kabupaten yang berada di Propinsi Sumatera Barat. Kabupaten Solok Selatan terbentuk dari proses pemekaran wilayah induknya yakni Kabupaten Solok yang resmi menjadi kabupaten sendiri pada tanggal 7 Januari 2004. Wilayah Kabupaten Solok Selatan mencakup wilayah seluas $3.356,20$ $\mathrm{km} 2$ yang terletak di bagian timur Propinsi Sumatera Barat. Secara geografis kabupaten ini berbatasan langsung dengan Propinsi Jambi di bagian selatan serta dengan tiga kabupaten lainnya yaitu Kabupaten Pesisir Selatan, Kabupaten Solok dan Kabupaten Dharmasraya masingmasing di bagian barat, utara, dan timur. Berdasarkan data BPS tahun 2011, jumlah penduduk Kabupaten Solok Selatan adalah sejumlah 147.369 jiwa (BPS, 2011) Sebagai kabupaten hasil pemekaran yang secara usia tergolong masih muda, Kabupaten Solok Selatan tidak terlepas dari berbagai persoalan yang timbul di berbagai sektor. 


\begin{tabular}{lrr}
\multicolumn{2}{c}{ Minimnya } & Sumber Daya \\
Manusia (SDM) & dan kualitas \\
infrastruktur & \multicolumn{2}{c}{ menjadi } \\
permasalahan & utama di
\end{tabular}
Kabupaten Solok Selatan (Pemkab Solok Selatan, 2018). Hal ini disebabkan oleh kurangnya jumlah penduduk angkatan kerja yang terdidik dan terlatih. Fenomena lemahnya SDM akan berbanding lurus dengan aspek pendidikan dan kesejahteraan masyarakat yang juga tergolong masih kurang. Akibatnya, jumlah masyarakat yang terserap di dunia kerja juga sangat sedikit jika dibandingkan dengan masyarakat dari kabupaten lainnya di Sumatera Barat. Selain aspek SDM, persoalan lain terkait dengan upaya menguatkan ketahanan wilayah Solok Selatan yaitu aspek sumberdaya alam. Pada dasarnya Solok Selatan memiliki potensi sumberdaya alam yang besar namun belum dimanfaatkan dengan maksimal karena kurangnya sumberdaya manusia lokal yang mumpuni. Berdasarkan peta geologis Solok Selatan terdapat potensi sumber daya mineral. terdiri dari mineral logam berupa tembaga, emas, dan perak; potensi panas bumi yang ditandai oleh munculnya mata air panas; serta bahan galian berupa batu gamping, pasir, dan batu sungai. Baru-baru ini pemerintah tengah mengembangkan pembangkit listrik tenaga panas bumi (geothermal) di Muara Labuh, Solok Selatan. Jika proyek ini dilaksanakan dengan baik tentu akan menopang perekonomian di Solok Selatan.
Selain potensi sumberdaya alam diatas, secara topografi wilayah Solok Selatan memiliki jenis tanah dengan tingkat hara yang tinggi dan sangat subur ssehingga daerah ini sangat cocok untuk pengembangan kegiatan pertanian, terutama tanaman holtikultura dan perkebunan. Implementasi 5 gatra yakni ideologi, politik, ekonomi, sosial budaya dan pertahanan keamanan merupakan tanggung jawab pemerintah bersama dengan masyarakat setempat serta sektor swasta untuk mewujudkannya.

\section{Urgensi Internalisasi Nilai-} nilai Ketahanan Nasional dalam Pembelajaran PPKn Tingkat SMP di Kabupaten Solok Selatan

Sebagai konsekuensi dari konsep desentralisasi melalui program otonomi daerah, maka aspek pendidikan sebagai salah satu indikator keberhasilan pembangunan masyarakat akan menjadi tanggung jawab setiap daerah dibawah koordinasi pemerintah pusat. Daerah menjadi pelaksana dalam mewujudkan pendidikan yang berkualitas berdasarkan pada kemampuan daerahnya. Menyadari akan hal tersebut, menurut Santoso (2006) maka gagasan tentang masalah kekuatan dan unsur-unsur apa saja yang ada dalam diri bangsa Indonesia serta apa yang seharusnya dimiliki agar kelangsungan bangsa Indonesia terjamin di masa-masa 
mendatang terus menguat. Hal tersebut disebabkan tiap daerah memiliki kekuatan dan kelemahan masing-masing yang berbeda dengan daerah lainnya. Kekuatan daerah hasil pemekaran tentu akan berbeda dengan daerah induk sebab daerah pemekaran baru akan memulai proses pembangunan yang terpusat dan terkonsentrasi secara mandiri dengan segenap kekuatan daerahnya. Berbeda dengan daerah induk yang telah lebih dahulu melaksanakan proses pembangunan.

$$
\text { Menyadari kondisi }
$$

ketahanan wilayah Solok Selatan yang masih tergolong lemah maka perlu upaya serius agar kondisi ini perlahan dapat terselesaikan. Sebab, lemahnya ketahanan suatu wilayah merupakan persoalan penting di tengah era globalisasi saat ini karena akan berdampak sistemik terhadap aspek-aspek lain. Pembangunan SDM yang masih terbengkalai dapat memicu kerawanan sosial dan menimbulkan persoalan lainnya jika tidak segera diselesaikan.Persoalan lain yang dapat timbul yaitu potensi kecemburuan sosial terhadap daerah lain yang lebih maju secara kualitas SDM dan infrastrukturnya. Kondisi ini dapat memicu konflik serta kerawanan sosial di masa mendatang. Perlu adanya perhatian dari pemerintah propinsi hingga pemerintah pusat untuk membenahi masalah- masalah tersebut yang dapat dimulai dari dunia pendidikan. Solusi yang dapat dilaksanakan yaitu dengan menginternalisasikan nilai-nilai ketahanan nasional dalam kurikulum pembelajaran di sekolah pada jenjang SMP. Internalisasi nilai-nilai Ketahanan Nasional dapat dilakukan melalui mata pelajaran Pendidikan Pancasila dan Kewarganegaraan di tingkat SMP karena secara disiplin $\operatorname{lmu}$, kajian ketahanan nasional termasuk kepada kajian kewarganegaraan. Perwujudan ketahanan nasional yang dimulai dari ketahanan pribadi setiap siswa di SMP di wilayah Solok Selatan dapat didefinisikan melalui astagatra ketahanan nasional yang terbagi atas gatra alami dan gatra buatan.

Pentingnya penanaman nilai-nilai ketahanan nasional sejak dini disebabkan karena kelangsungan hidup masa mendatang akan dipengaruhi oleh kualitas generasi mudanya. Generasi muda merupakan agen perubahan yang pada masanya akan menjadi pemimpin perubahan di masyarakat. Oleh karena itu diperlukan generasi muda yang paham dan arif dengan kondisi wilayah dan memiliki rasa tanggung jawab terhadap kemajuan wilayah Solok Selatan. Penanaman nilai-nilai ketahanan nasional dalam proses pembelajaran PPKn di sekolah dapat menjadi salah satu solusi agar siswa memahami konsep Ketahanan Nasional dan dapat 
Urgensi Internalisasi nilai..

mengukur kelemahan dan secara positif dalam rangka kekuatan wilayah mereka akselerasi pembangunan Solok sehingga dapat berkontribusi Selatan untuk masa mendatang.

\section{REFERENSI}

Aini, N. (2012). Domestifikasi Etnisitas: Pemekaran Wilayah dan Rutinisasi Kekerasan antar Etnis di Maluku Utara. Jurnal Pemikiran Sosiologi, 1(1), 103-115.

BPS. (2011). Kabupaten Solok Selatan Dalam Angka 2011. BPS Kabupaten Solok Selatan. Solok Selatan.

Djadijono. (2006). Membangun Indonesia dari Daerah. Yogyakarta: Kanisius.

Pemkab Solok Selatan. (2018). Sekilas Solok Selatan. Retrieved February 15, 2018, from www.solselkab.go.id

Pratikno. (2003). Dalam Kompleksitas Persoalan Otonomi Daerah di Indonesia. Yogyakarta: Pustaka Pelajar.

Santoso. (2006). Rencana Pembelajaran dan Metode Pembelajaran Serta Metode Evaluasi Hasil Pembelajaran Pendidikan Kewarganegaraan-Kurikulum Perguruan Tinggi berbasis Kompetensi. Special Materials Services, Manitoba Education.

Susanti. (2014). Dampak Pemekaran Wilayah terhadap Kesejahteraan di Lampung Utara. Jurnal Ekonomi Pembangunan, 3(2).

UU No. 22 tahun 1999

UU No. 22 tahun 2004

UU no 32 tahun 2004 Tentang Otonomi Daerah 